DOI:

\title{
A rare case of ankylosing spondylitis with severe temporomandibular joint and dental involvement
}

\author{
Ciddi temporomandibular eklem ve diş tutulumu olan nadir bir ankilozan spondilit olgusu
}

Meryem YILMAZ KAYSIN, Ilknur AKTAS, Feyza UNLU OZKAN

\begin{abstract}
Ankylosing spondylitis (AS) is a chronic inflammatory disease that primarily affects the axial skeleton, resulting in functional deterioration. Temporomandibular joint (TMJ) ankylosis is characterized by bony or fibrous adhesion of the anatomic joint components, which results in limited mouth opening. Despite the high prevalence of the disease, ankylosis of the TMJ and tooth secondary to AS are rare conditions. Here, a patient with AS admitted to the outpatient clinic with a chief complaint of TMJ pain and restricted mouth opening was diagnosed with TMJ and dental sclerosis. The patient's dental history included fracture of a wisdom tooth during an attempted extraction and difficulty in mouth opening. TMJ and dental ankylosis should be considered in patients with AS with a poor dental history and difficulty in mouth opening. For such suspected cases, a panoramic radiograph of the jaws and teeth should be obtained to detect abnormalities.
\end{abstract}

Keywords: Ankylosing spondylitis, Temporomandibular joint, Tooth

Meryem Yilmaz Kaysin (凶), Ilknur Aktas, Feyza Unlu Ozkan

Department of Physical Therapy and Rehabilitation, Fatih Sultan Mehmet Training and Research Hospital, Istanbul Health Sciences University, Istanbul, Turkey

e-mail:drmeryem84@hotmail.com

Submitted / Gönderilme: 23.07.2017

Accepted/Kabul: 11.09 .2017

\section{ÖZ}

Ankilozan spondilit (AS) primer olarak aksiyel iskeleti tutan ve fonksiyonel bozukluğa yol açan kronik enflamatuvar bir hastalıktır. Temporomandibular eklem (TME) ankilozu, eklem bileşenlerinin kemik veya fibröz adezyonu ile karakterize olup, ağız açıklığında kısıtlanma ile sonuçlanmaktadır. Hastalığın yüksek prevelansına rağmen AS'e bağlı TME ve diş ankilozu oldukça nadir bir durumdur. $\mathrm{Bu}$ olgu sunumu ile TME ağrısı ve ağız açıklığında kısıtlılık ile polikliniğimize başvuran ve TME ve diş ankilozu tanısı alan bir AS olgusu sunmayı amaçladık. Hastanın ağız açıklığında kısıtlllık ve zorlu bir diş çekimi öyküsü mevcuttu. Kötü dental hikayesi olan ve ağız açmakta zorluğu olan AS hastalarında, TME ve diş ankilozu mutlaka düşünülmelidir. Şüpheli olgularda çene ve diş anormalliklerini tespit etmek için panoramik ağız grafisi ile hasta değerlendirilmelidir.

Anahtar kelimeler: Ankilozan spondilit, Temporomandibular eklem, Diş

\section{Introduction}

Ankylosing spondylitis (AS) is a chronic inflammatory disease of the axial skeleton that manifests as back pain and progressive stiffness of the spine. AS can also involve the peripheral joints and enthesitis $[1,2]$. It usually affects males below the age of 50 [3]. Patients with AS may experience pain, stiffness, and swelling of the joints outside the spine. Peripheral arthritis occurs in approximately $35 \%$ $50 \%$ of patients with AS over the course of the disease [4]. The temporomandibular joint (TMJ) is one of the most important joints in the human body, and sporadic cases of TMJ ankylosis may occur in patients with AS as the peripheral joint involvements [5].

\section{Case Report}

A 32-year-old male with a 15-year AS history who was followed up in a rheumatology clinic was admitted to the 
outpatient clinic with a complaint of TMJ pain. He had no history of trauma or infection of TMJ. On presentation, he had been undergoing intravenous infliximab therapy for 6 months ( $>5 \mathrm{mg} / \mathrm{kg}$ per 8 weeks) and had irregularly undergone medical treatments with methotrexate and various non-steroidal anti-inflammatory drugs, bisphosphonates, and calcium-vitamin D complexes previously. The past dental history of the patient showed that his right wisdom tooth was fractured during extraction at the age of 20 .

A physical examination revealed the postural abnormalities with increased dorsal kyphosis and decreased cervical and lumbar lordosis (Figure 1). The occiput-to-wall distance was $26 \mathrm{~cm}$ and chest expansion was $0 \mathrm{~cm}$. Spinal mobility, measured with the lumbar Modified Schober test was $0 \mathrm{~cm}$, and lumbar lateral flexion was $4.4 \mathrm{~cm}$. Bilateral

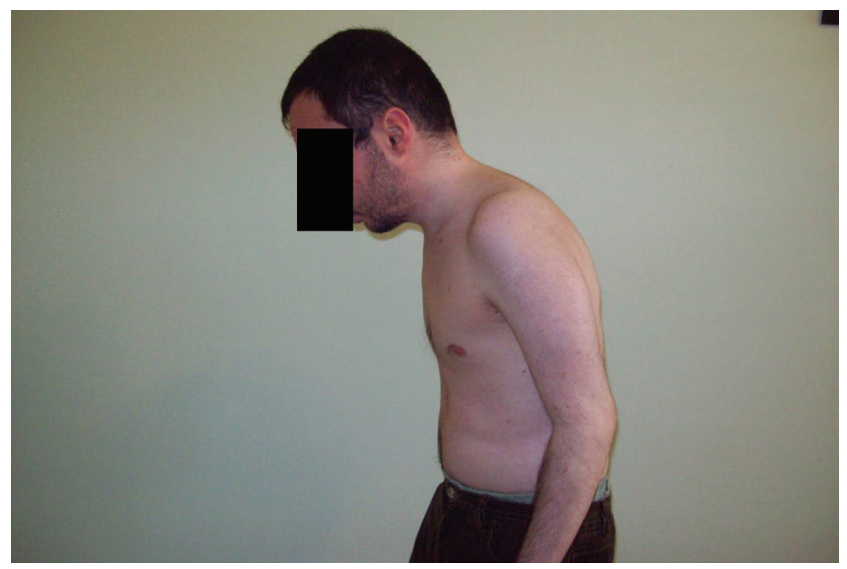

Figure 1. Increased dorsal kyphosis and decreased lumbar lordosis of the patient knees were ankylosed at $90^{\circ}$ flexion. He had bilateral deformities of the hands and fingers. The Bath Ankylosing Spondylitis Disease Activity Index was 1.6 and the Bath Ankylosing Spondylitis Functional Index was 38.5. He was able to walk with the aid of a walking stick only at home. His bilateral TMJs were tender with pressure, and the maximal interincisal opening was $20 \mathrm{~mm}$ (Figure 2). This condition was presumed to be associated with peripheral joint involvement with AS.

According to the patient's history obtained from his dentist, the patient's wisdom tooth was fractured during an attempted extraction. Panoramic radiography of the jaw and tooth performed at that time revealed bony ankylosis of TMJs and nearly all teeth (Figure 3 ). The tooth extraction was terminated because of an increased risk of mandible fracture.

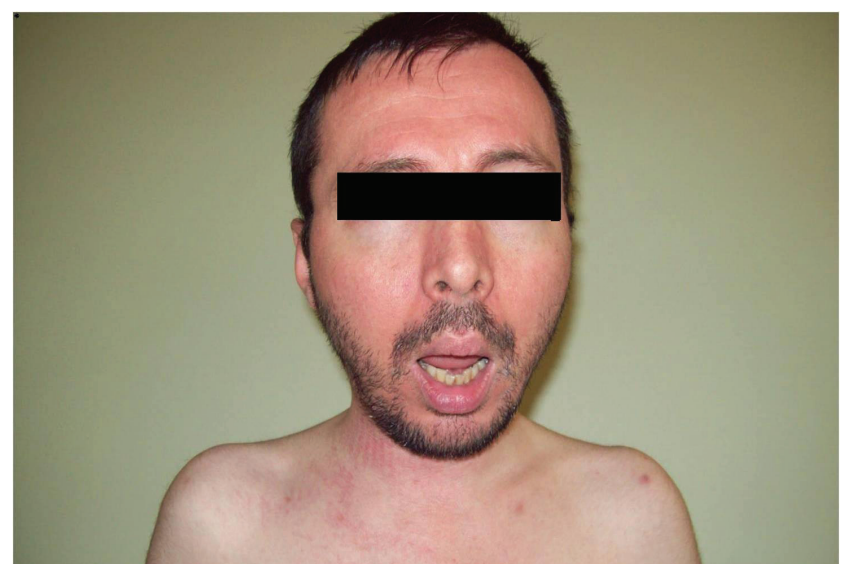

Figure 2. Limited interincisal opening of the patient

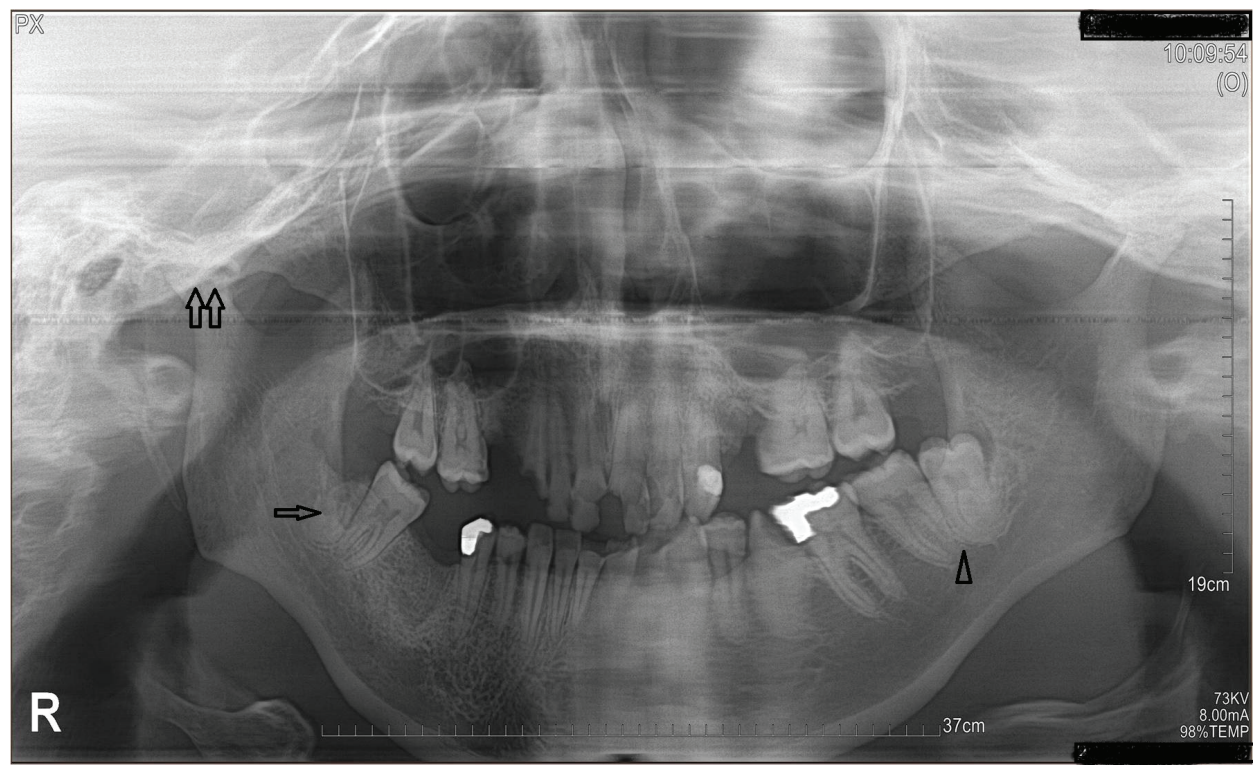

Figure 3. A panoramic radiograph of TMJs and teeth. Arrow shows the fractured right wisdom tooth during extraction process. Double arrow shows the bony ankylosis of temporomandibular joint. Arrowhead shows the dental ankylosis 
The patient was informed of his condition and instructed to take care of his dental health. He was prescribed indomethacin $150 \mathrm{mg}$ /day. Meanwhile, the intravenous infliximab therapy ( $5 \mathrm{mg} / \mathrm{kg} /$ per 8 weeks) was continued. Besides this, the patient was included in an intensive physical therapy program with active/ passive mouth opening exercises. Although, some improvements were obtained, the patient was recommended to have an operation, in order to acquire optimal mouth opening. The patient has given written informed consent for publication of his medical record and images.

\section{Discussion}

Ankylosing spondylitis is a chronic inflammatory disease of the family of seronegative spondyloarthropathies that mainly affects the axial skeleton, peripheral joints, and extraarticular tissues. Main pathologic changes are fibrosis and ossification of the tendons and partial ligament insertion, due to increased inflammation. Importantly, TMJs may be involved with consequent ligament ossification, bony erosions, condylar flattening, disk destruction, and reduced range of motion [6].

Temporomandibular joint is one of the most important joints in the human body and consists of a condylar process of the mandible, glenoid fossa, articular disc, and joint capsule [7]. It is an atypical diarthrodial synovial joint with rotational and translational movements. The inherent fibrocartilage surface structure of TMJ creates the tendency of involvement by AS. TMJ involvement in AS is not uncommon, and patients with TMJ involvement tend to have more extensive spinal and peripheral joint disease, as observed in our case [8]. Helenius et al., showed that TMJ erosions in patients with AS and the other spondyloarthropathies are correlated with an increased frequency of the HLA-B27 antigen [9]. However, the HLA-B27 status of our case was unknown because of the patient's discordance to follow-up.

Available literature suggests that TMJ involvement occurs in $4 \%-35 \%$ of patients with AS, usually at 10 30 years after onset of the disease. In this context, TMJ movements should be evaluated in patients with long-term AS [10]. Accordingly, our patient had a disease history of approximately 15 years.

Major symptoms of TMJ involvement are pain, stiffness, and restriction of jaw movements, as was observed in our case. Nearly all ankylosis cases have problems with mastication, digestion, speech, appearance, access to routine dental procedures, and psychological status [8]. Pain while eating and progressive limitation of mouth opening accompanied by radiographic evidence of joint degeneration, such as narrowing of the joint space, osteophyte formation, erosion, and ankylosis, are characteristics of TMJ involvement [11]. Maximal mouth opening is evaluated by measurement of the interincisal distance, where $36-38 \mathrm{~mm}$ is considered as the lower limit in adults. A study by Ezirganlı et al., showed that the maximum mouth opening distance for males and females was 50.38 and $46.35 \mathrm{~mm}$, respectively [12]. Accordingly, the interincisal distance in our case was considered to be highly limited being at $20 \mathrm{~mm}$.

A literature review retrieved no reports of dental involvement in AS, although there were some cases of chronic periodontitis [13]. However, in our case, severe dental ankylosis was identified in addition to TMJ ankylosis. Therefore, dental involvement might not be surprising in such ligamentous inflammatory diseases.

Limitation of mouth opening due to TMJ ankylosis, dental ankylosis, and other AS-related conditions, such as atlantoaxial subluxation, osteoporosis, and immunosuppressive medications, may cause poor oral hygiene and some complications during dental procedures. Even a simple dental extraction may be very challenging for the dentist, as we observed in our case [6].

Prior to each oral manipulation, lateral cervical and panoramic radiographs of the jaws and teeth should be obtained after careful manual examination. These simple radiographs offer information about cervical fusion, atlantoaxial subluxation, and dental/TMJ ankylosis as well as the extent of TMJ damage secondary to AS [14].

The treatment options for limited mouth opening due to TMJ ankylosis range from physiotherapy involving intensive mouth-opening exercises to surgical interventions, such as autogenous bone grafts, distraction osteogenesis, and TMJ replacement [15]. Anti-inflammatory medications are still a major part of symptomatic treatment [16].

In conclusion, TMJ and dental ankylosis should be considered in patients with long-term AS. Early suspicion and diagnosis could prevent deterioration of the disease and improve the patient's orodental health and quality of life.

Conflict of Interest: None declared

Financial Disclosure: No financial support was received for this study. 


\section{References}

1. Ghasemi-rad M, Attaya H, Lesha E, et al., Ankylosing spondylitis: A state of the art factual backbone. World J Radiol 2015;7,:236-52. doi: 10.4329/wjr.v7.i9.236

2. Dougados M, Baeten D. Spondyloarthritis. Lancet 2011;377(9783): 2127-37. doi: 10.1016/S0140-6736(11) 60071-8

3. Dougados M, Linden SVD, Juhlin R, et al., The European Spondylarthropathy Study Group preliminary criteria for the classification of spondylarthropathy. Arthritis Rheum 1991;34, 1218-27.

4. Vander Cruyssen B, Ribbens C, Boonen A, et al., The epidemiology of ankylosing spondylitis and the commencement of anti-TNF therapy in daily rheumatology practice. Ann Rheum Dis 2007;66: 1072-77. doi: 10.1136/ ard.2006.064543

5. Oliveira LSDAF, de Oliveira-Santos C, de Melo DP, et al., Unilateral bony ankylosis of the temporomandibular joint in a case of ankylosing spondylitis. Maxillofac Oral Surg 2013;17:213-17. doi: 10.1007/s10006-012-0365-2

6. Mehdizadeh M, Poorsattar BMA. Surgical orodental implications in ankylosing spondylitis. Dent Res J 2012;9:807-11.

7. Matsumoto A, Sasai T, Matsumoto K. A temporomandibular joint ankylosis with periarticular tissue calcification long followed up case. J Arthritis 2015;4: 150. doi:10.4172/21677921.1000150 .

8. Felstead AM, Revington PJ. Surgical management of temporomandibular joint ankylosis in ankylosing spondylitis. Int J Rheum 2011; Article ID 854167. doi:10.1155/2011/854167 .
9. Helenius LMJ, Hallikainen D, Helenius I,et al. HLA-DRB1* alleles and temporomandibular joint erosion in patients with various rheumatic diseases. Scand J Rheum 2004;33:24-9. doi: 10.1080/03009740310004603

10. Brkić Z, Pijevčević N, PavlićV, Petronijevic M. Oral rehabilitation of patient with temporomandibular joint ankylosis caused by ankylosing spondylitis: A case presentation. Vojnosanit Pregl 2017; 74: 374-77. doi: 10.2298/VSP150522189B

11. Sidebottom J. Guidelines for the replacement of temporomandibular joints in the United Kingdom. Br J Oral Maxillofac Surg 2008;46:146-47. doi: 10.1016/j. bjoms.2006.12.001

12. Ezirganlı Ş, Kara Mİ, Küçük D, et al., Investigation amount of maximum mouth opening and association with temporomandibular joint disorders in Turkish adult population. J Dent Fac Ataturk Uni 2013;21:57-62.

13. Keller JJ, Kang JH, Lin HC. Association between ankylosing spondylitis and chronic periodontitis: A population-based study. Arthritis Rheum 2013;65:167-73. doi: 10.1002/ art.37746

14. Chow TK, Ng WL, Tam CK, et al., Bilateral ankylosis of temporomandibular joint secondary to ankylosing spondylitis in a male Chinese. Scand J Rheumatol 1997;26:133-34.

15. Sporniak-Tutak K, Janiszewska-Olszowska J, Kowalczyk R. Management of temporomandibular ankylosis-compromise or individualization-a literature review. Med Sci Monit 2011;17:111-6.

16. Arora P, Amarnath J, Ravindra SV, Rallan M. Temporomandibular joint involvement in ankylosing spondylitis. BMJ Case Rep 2013; 2013: bcr2013009386. doi: 10.1136/bcr-2013-009386. 